partment of Psychology at Boston University has done a study of 3,200 male twins in which both twins served in the United States military between 1965 and 1975 . He found that in general adult antisocial behaviours were more influenced by genetic factors than were juvenile behaviours. Juvenile antisocial behaviours were more strongly influenced by the family environment than were adult behaviours. It was found that non-violent antisocial behaviours, both adult and juvenile, were more concluded that, "Genetic influences play an important role in determining why individuals differ from one to another with regard to antisocial behaviour, but the environment ... is also important."

Presenting a review of adoption studies of criminal behaviour, Sarnoff Mednick, of the Center for Longitudinal Research at the University of South Carolina, observed that "The empirical evidence suggests that some significant part of the etiology of criminal activity involves characteristics which are partially under the control of heritable factors."

Gregory Carey of the Institute of Behavioral Genetics at the University of Colorado, pointed out that in seven twin studies identical twins show more similarities in their antisocial behaviour than fraternal twins, while six adoption studies report a significant correlation between antisocial behaviour of adoptees and that of the adoptees' genetic relatives with whom they were not raised.

The twin studies show heritability factors of 0.4 to 0.5 for violent and aggressive behaviour, on a scale of 0 to 1 , where no heritability is 0 and complete heritability is 1. According to Carey, "The major quesheritable than violent behaviours. Lyons

tions to be asked are how individual differences in DNA ultimately translate into individual differences in aggression, theft, robbery, violence, and other behaviours in the 'antisocial' category."

Carey predicted that so many genes are involved that it would be impractical to 'treat' criminal behaviour through genetic engineering.

However, pharmaceutical companies are said to have expressed an interest in the findings of David Goldman at the Laboratory of Neurogenetics of NIH's National Institute on Alcohol Abuse and Alcoholism. $\mathrm{He}$ said at the conference, "Direct gene analysis and genetic linkage have identified structural variants in genes involved in neurotransmitter functions and some progress has been made towards relating these genetic variants to antisocial personality and other behaviors."

The clearest example of a genetic link with aggression is in a Dutch family studied by Han Brunner of the University Hospital of Nijmegen in The Netherlands. In the study, reported in Science (262, 578-580; 1993) Brunner and his colleagues found that men in the family with a history of violent behaviour had a mutation in the gene for monoamine oxidase $\mathrm{A}$, an enzyme that is involved in the metabolism of neurotransmitters. However, Brunner told the conference that there is no evidence to suggest that monoamine oxidase A deficiency has any role in producing abnormal behaviour in the general population. Moreover, he pointed out that drugs used to treat depression, which inhibit monoamine oxidase enzymes, do not make people aggressive.

NUALA MORAN London

\section{Electronic guide for clinicians}

Physicians struggling to keep up to date now have a new ally. An 'electronic' journal $^{*}$, the Cochrane Database of Systematic Reviews, to be launched later this month in London, will inform medical practitioners quickly which treatments have been shown to work.

The database is the product of an international venture known as the Cochrane Collaboration. This global network consists of some 200 specialist volunteers who have agreed to follow rigorous methodological ground rules to draw up critical overviews of clinical practice.

The database's first 'issue' will provide
30 systematic reviews of treatments for stroke, schizophrenia, parasitic diseases and problems in pregnancy and childbirth. Ultimately, all areas of clinical care will be covered, as the Collaboration recruits new volunteers. Each review will be regularly updated in the light of new evidence, largely from randomized controlled trials, and critical feedback.

GAIL VINES Cambridge

* More information from the UK Cochrane Centre, Summertown Pavilion, Middle Way, Oxford OX2 7LG, UK.

Fax (+44) (0) 1865-516311; Internet, general@cochrane.co.uk

\section{DID YOU KNOW ...?}

Plans to establish a national bioethics board in the US move ahead

As Nature Medicine went to press, President Bill Clinton's National Science and Technology Advisory Council was expected to approve plans for the formation of a National Biomedical Ethics Advisory Committee.

This group, which will include scientists, philosophers and theologians, will assess the ethical implications of biomedical developments that may have a wide-ranging impact on public policy. Though the committee will be able to evaluate any area that seems relevant, its priorities will be how to handle genetic information about people and a review of the guidelines governing human subject research.

The Office of Science and Technology Policy at the White House will now seek Clinton's approval. If this is, as is expected, forthcoming, the new committee could be in place for the next fiscal year which begins in October 1995. It will have an annual budget of about $\$ 2$ million, culled from the discretionary funds of a number of agencies.

Helen GavaghaN Washington, DC

\section{Nutritionist 'Rama' honoured}

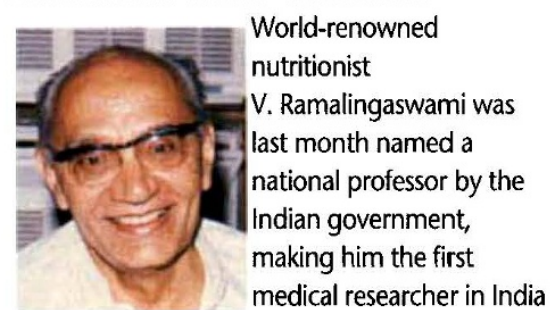

to receive the country's top honour given to working scientists over the age of 65 . Only 12 people have been given this title over the past 45 years, one of them being the late physicist and Nobel laureate, Chandrasekara Venkataraman.

Rama, as he is known to his friends, headed the Indian Council of Medical Research until his retirement in 1982, when the World Health Organization made him chairman of its global advisory committee on medical research, a position that he held until 1986. Elected to the Royal Society that same year, Ramalingaswami is also a fellow of the Karolinska Institute in Stockholm, Sweden, and foreign associate of the US National Academy of Sciences.

At 74, Ramalingaswami continues to conduct research on malnutrition at the All-India Institute of Medical Sciences in New Delhi, which he once headed. As national professor, Ramalingaswami says that he intends to continue with his work on liver diseases and iodine-deficiency disorders. The professorship lasts for 5 years.

K. S. JAYARAMAN New Delhi 